\title{
Blame the victims? Refugees, state capacity, and non-state actor violence
}

\author{
Tobias Böhmelt \\ Department of Government, University of Essex \\ Vincenzo Bove \\ Department of Politics and International Studies, University of Warwick \\ Kristian Skrede Gleditsch \\ Department of Government, University of Essex \& Peace Research Institute Oslo (PRIO)*
}

\begin{abstract}
Existing research argues that refugee inflows may increase the risk of domestic conflict, particularly civil war that, by definition, involves the state as an actor. However, many of the postulated mechanisms linking refugees to a higher risk of such conflict pertain to tensions with locals, which do not necessarily involve any grievances against government authorities. We contend that it is more likely to identify an association between refugees and non-state actor violence, i.e., armed violence between organized non-state groups, neither of which pertains to the state. We also claim that the extent to which refugees are associated with a higher likelihood of non-state conflict depends on the capacity of governments to manage and mitigate risks. We report evidence that refugee populations can be linked to an increased risk of non-state conflict, as well as for a mitigating effect of state capacity on the risk of non-state conflicts in the presence of refugees. We do not find a clear effect of refugee populations on civil war, suggesting that the link depends on existing conflict cleavages relevant to mobilizing refugees or locals. Our research helps to shed light on the relevant security consequences of managing refugee populations. Despite the common arguments portraying refugees as security risks in developed countries, the risk of non-state conflict applies primarily to weak states that have been forced to shoulder a disproportionate burden in hosting refugees.
\end{abstract}

Keywords: Non-state conflict; refugees; state capacity; quantitative analysis

TOBIAS BÖHMELT, b. 1982, PhD in International Relations (University of Essex, 2010); Professor at the University of Essex (2013-); current research interests: environmental politics, international mediation, and civil-military relations.

VINCENZO BOVE, b. 1980, PhD in Economics (Birkbeck College, University of London, 2011); Reader at the University of Warwick (2014-); current research interests: peacekeeping operations, migration, conflict and development, civil-military relations, and military spending.

KRISTIAN SKREDE GLEDITSCH, b. 1971, PhD in Political Science (University of Colorado, Boulder, 1999); Professor at the University of Essex (2005-); Research Associate, Peace Research Institute Oslo (2003-); current research interests: violent and non-violent conflict, democratization, and political violence.

We thank the special issue editors, Alex Braithwaite, Idean Salehyan, and Burcu Savun as well as three anonymous reviewers for useful comments and suggestions. We are also grateful to Faten Ghosn, Arzu Kibris, Adam Lichtenheld, John McManus, and participants at the workshop 'Political, Economic, Social, and Legal Aspects of Hosting Migrants and Refugees', Istanbul, July 4-8, 2017, supported by the British Council Newton Fund (grant number: RLWK6-261786650), as well as audiences at seminar presentations at the Universities of Mannheim and Warwick for their valuable feedback.

\footnotetext{
*Email address of corresponding author: tbohmelt@essex.ac.uk
} 


\section{Introduction}

A large literature has emerged suggesting that refugees can be associated with a higher risk of violent civil conflict within hosting countries. Most of this research focuses on conventional civil war or on how refugees are likely to exacerbate tensions within countries that in turn are more likely to lead to violent disputes involving the state. For example, the 'refugee-warrior thesis' highlights how refugees in camps could be mobilized to participate in violent uprisings against a government, with the 1970 Black September uprising of Palestinian refugees in Jordan as the canonical example (see Zolberg et al., 1989). However, there are also many examples where refugee flows have not been associated with violent conflict at all, or where refugees may have been linked to other forms of violence, distinct from conventional civil war. In particular, numerous events involving violence are not initiated by refugees, are not directed at the state, and do not involve the government as an actor in any meaningful way (see also Gleditsch \& Bartusevičius, 2018).

In one of the largest contemporary refugee crises in South-East Asia, for example, an estimated 40,000 Rohingya have fled violent persecution in Myanmar and sought refuge in India by mid-2017. Many Rohingya in India have become victims of violent persecution from hostile local populations. In early 2017, the Jammu and Kashmir National Panthers Party in Northwest India launched a series of demonstrations calling for the Rohingya to be expelled from the province. And beyond simply exerting voice or raising political demands, there have been many threats to use violence as well as reports of violent attacks against Rohingya refugees. However, these violent events do not fit the traditional definition of civil war or the template of the 'refugeewarrior thesis' (see Zolberg et al. 1989), which focus on security risks arising from refugees taking up arms against the government in response to marginalization and immiseration. Although some have voiced concerns over the potential for radicalization and recruitment among the Rohingya refugees, there is no evidence that these have joined insurgent groups in Kashmir and there appears to be little mobilization over the common Muslim religious identities shared between the Indian Muslims and the Rohingya. Moreover, the violence that has been perpetrated against Rohingya refugees is neither carried out nor implicitly endorsed by the government.

The case of the Rohingya in India illustrates the need to look beyond the effects of refugees on conventional conflict and consider the possible implications for non-state violence, i.e., violence between organized armed groups, neither of which pertains to the state (Melander et al., 2016, Sundberg et al., 2012). Although different forms of (organized) violence may share some common underlying causes and can occur simultaneously (see, e.g., Cunningham \& Lemke, 2013), there are also important differences. Non-state conflict involves fighting among groups outside of and not affiliated with the state that are identified by shared communal identities, and are often fought over land distribution, access to natural resources, or result of socioeconomic inequalities (Fjelde \& Østby 2014). Partially because of data availability, however, existing quantitative literature has largely tested theories about refugees and violence exclusively using data on conflict involving the state ${ }^{1}$ Qualitative research has

\footnotetext{
${ }^{1}$ In a recent exception, Fisk $(2018)$ explores violence against civilians in refugee-populated communities. She finds that refugee populations positively correlate with civilian victimization, particularly in areas with larger self-settled populations, i.e., those living among the local population who do not have official legal status as refugees (see also Fisk 2019 .
} 
acknowledged other forms of violence more systematically. Onoma (2013), for example, contributes in significant ways to our understanding of the refugee-conflict nexus by focusing on refugees as victims of violence. In light of this, there has been a reported increase in threats against refugees in European countries that have hosted larger numbers of refugees from the Syrian civil war. However, in countries such as Germany, concerted efforts by the police have been undertaken against people suspected of planning violent responses, and there has been considerable investment in efforts to monitor social media and prevent the diffusion of such acts. In this article, we build on previous studies by, e.g., Onoma (2013) on refugee populations and the risk of non-state violence and consider the potential mitigating influence of state capacity.

We first take stock of the literature on the security implications of refugees and the dire predictions that some have derived from the current refugee crisis based on their interpretation of existing research. We then outline the key arguments why refugees may be associated with a higher risk of non-state violence as well as the mechanism through which governments can intervene and mitigate risks. We contend that the prospects for such state interventions, if supported by a sufficiently large amount of state capacity, can potentially moderate how refugee populations are associated with non-state conflict. We empirically test these claims, combining the Uppsala Conflict Data Program's (UCDP) Non-State Conflict Dataset Melander et al., 2016, Sundberg et al. 2012 with data on refugee populations from the United Nations High Commissioner for Refugees (UNHCR) Population Statistics Reference Database $2^{2}$ Our analyses show that a larger number of refugees can be associated with a higher non-state conflict risk, but not a higher risk of civil war, i.e., state-based conflict. We also report evidence for the moderating effect of state capacity.

Our research has important implications for scholarship and policy. On one hand, we improve our understanding of how postulated drivers of intrastate conflict are related to specific types of violence (or not), as we show that refugees are less likely to be related to 'traditional' civil wars in their destination country, but could be associated with intrastate violence among non-state actors. On the other hand, we also help clarify the relevant security consequences of hosting refugees as well as why certain fears of widespread civil war are less likely to be borne out. Our findings provide insights that can inform policymakers and public responses to address the security implications stemming from refugee populations. In particular, they can help to develop a more adequate understanding of the relevant concerns and challenges to states in dealing with the serious refugee crisis playing out at the present time. Our analysis lends little support to the alarmist calls for restricting refugee access in developed countries on security grounds, and the risk of non-state conflict primarily applies to the developing countries that face a disproportionate impact of the current refugee crisis and also have the least capacity to cope with large refugee populations.

\section{The contemporary refugee crisis and conflict potential}

The scale of the contemporary refugee crisis is undeniable (Hatton, 2016): the global number of refugees has risen rapidly with the Syrian civil war, and there were more than 21 million refugees globally by the end of 2015

\footnotetext{
${ }^{2}$ Available online at http://popstats.unhcr.org/en/time_series
} 
according to the UNHCR. Existing work has identified several different ways in which an increase in a state's refugee population might give rise to civil conflict. Based on the postulated positive links between refugees and civil war in this literature, one should expect the current rise in refugees to go together with an increase in new outbreaks of civil war, at least for refugee populations in neighboring countries. An increase in both refugees and civil wars appeared to take place in the early 1990s, and there was at least clear anecdotal evidence that refugees often became involved in civil wars in other neighboring states, in line with the refugee-warrior proposition (see Salehyan \& Gleditsch, 2006, Zolberg et al., 1989). However, this coincided with a period where we saw many refugees crossing borders in large regional clusters of interrelated and contagious conflicts as in, e.g., the Great Lakes Region of Africa (Gleditsch, 2007). It is difficult to detect a similar corresponding increase in the number of contemporary civil wars in light of the current rise in refugees, and the incidence of civil war is generally known to have declined since the mid-1990s, aside from the Syrian civil war (Gleditsch \& Clauset, 2018). This can be confirmed by looking at internal state-based conflicts in the UCDP/PRIO Armed Conflict Dataset (Gleditsch et al. 2002; Melander et al. 2016) in the left panel of Figure I. As shown in the right panel of Figure I, however, the number of UCDP internal non-state conflicts appears to have increased notably over the same period. Considering Figure I, it is pertinent to ask if some of the recorded increase in non-state conflict may be associated with population movements.

Figure I. Conflict trends, 1989-2015
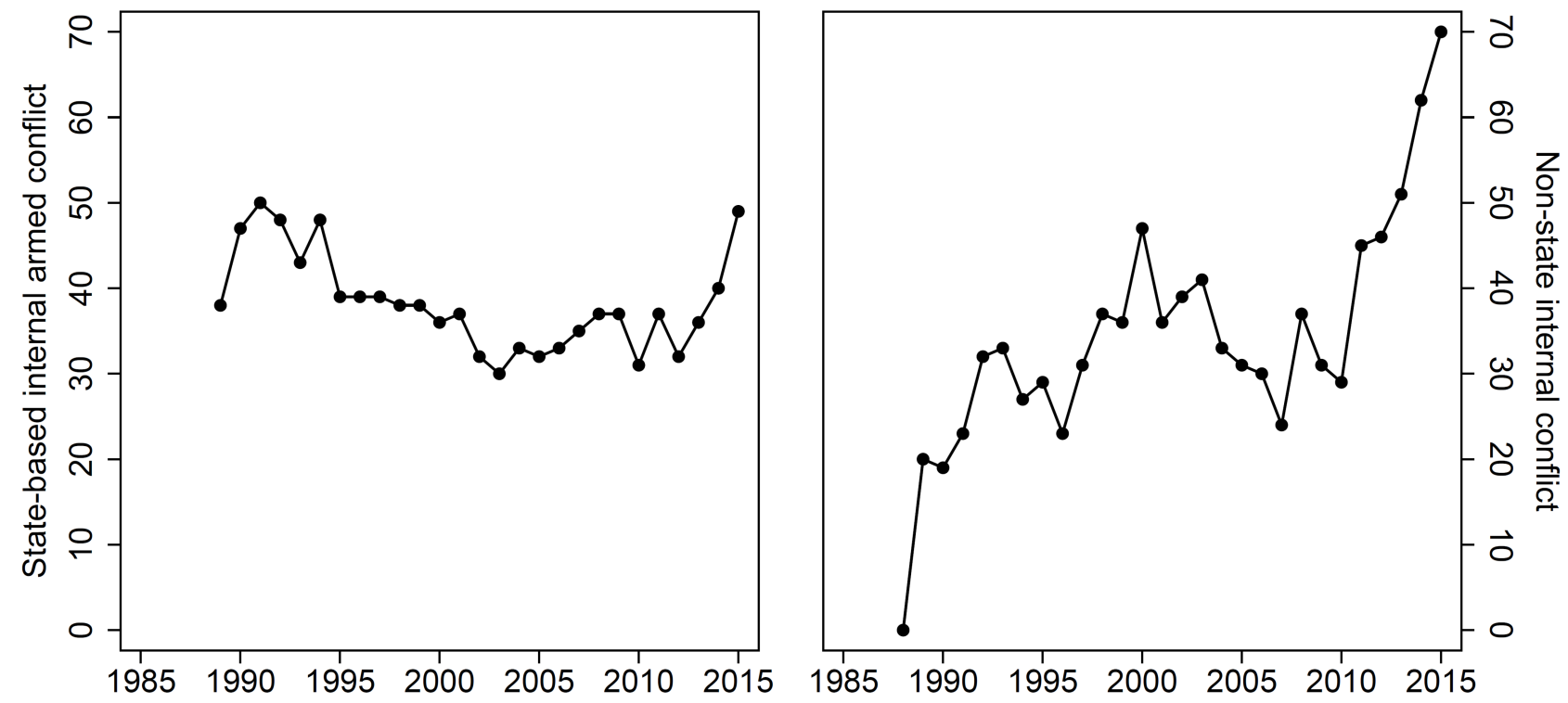

Note: State-based internal armed conflicts (totals by distinct incompatibilities) in the left panel and non-state internal conflict incidence (total) in the right panel. Time period is limited to 1989-2015 as data for non-state conflict are only available as of 1989.

States can experience a number of difficulties when trying to manage the arrival of large numbers of refugees. These difficulties could undermine local livelihoods and generate popular grievances, and induce further negative externalities affecting host states in a number of direct and indirect ways Adamson, 2006, Dowty \& Loescher, 1996; Buhaug \& Gleditsch, 2008; Salehyan \& Gleditsch, 2006, Bove \& Böhmelt, 2016; Milton et al., 2013). However, differences in state capacity can have important effects on the risk of domestic violence at the outset, and the relevance of the specific mechanisms differs between institutionally and economically developed and less 
developed states (Fearon \& Laitin, 2003). State capacity shapes the success of challenges by violent opposition groups, as stronger government capacity can reduce the ability of rebels to take advantage of national grievances as well as the likely support for rebels (de Rouen \& Sobek, 2004). State capacity also influences a government's ability to prevent conflict and to withstand the spread of violence from neighboring territories (Braithwaite, 2010).

Although existing research provides many contributions and helpful insights, it does not engage directly with whether and how refugees can provide opportunities for unconventional forms of political violence among nonstate actors. In fact, past works by e.g., Salehyan \& Gleditsch (2006) suggest that refugees can increase the risk of civil war by, e.g., altering the ethnic balance of host societies, worsening already poor economic conditions, and by facilitating the traveling of weapons and mobilized belligerents across borders. Yet, grievances against the state are not always present when there is social tension, and the state as an actor is not necessarily involved in episodes of violence. Salehyan \& Gleditsch (2006) highlight the role of refugees from neighboring countries in conflict, which are more likely to have ties to local populations' cleavages, and argue that refugees hosted in countries far from the origin were unlikely to give rise to a higher risk of civil war. Gleditsch \& Bartusevičius (2018) further demonstrate the role of potential incompatibilities and contend that refugee flows from neighboring countries are primarily associated with a higher risk of conflict when countries have observed cleavages that can give rise to conflict.

We complement existing works on civil wars by showing that refugee populations may also be associated with non-state conflict. Moreover, we investigate in detail under which circumstances more refugees can increase the risk of violence. There are a number of scope conditions and intervening factors that can mitigate or exacerbate the impact of population movements on different types of violence in the host state in diverse and complex ways, such as the presence of pre-existing incompatibilities, the type of grievances against the state, the cultural differences between native populations and refugees, and other surrounding contextual parameters. We contribute to furthering this line of research by exploring how state capacity, or the lack thereof, moderates the negative externalities of large population movements on the risk of violent conflict in receiving states. Our research builds on and extends earlier studies on refugees and conflict by investigating some of the contextual factors that may enhance or hamper violence diffusion through refugee flows (Salehyan \& Gleditsch, 2006), paying particular attention to non-state violence, which is commonly defined as communal conflict (see Sundberg et al. 2012). We argue that refugee populations can be linked to non-state violence, but that this threat affects weaker states to a much greater degree than countries with stronger state capacity.

\section{Non-state violence, refugees, and state capacity}

\section{Refugees and non-state violence}

As discussed above, most of the existing literature concentrates on violent conflict that directly targets the state either over control of the government or for territorial secession. We focus on how tensions between refugees 
and the local population could also lead to non-state violence in cases where conventional civil war may be less likely. Non-state conflict and refugees are plausibly linked through various mechanisms that relate to the costs on a host society (see also Savun \& Gineste, 2017). These mechanisms may also suggest that refugees can become 'targets' of non-state violence. And in other cases, we might observe an increase in the risk of local groups fighting each other, where refugees themselves are not directly involved in violent conflict.

In what follows, we provide an argument for the macro-level effect of refugees on non-state violence. The perceived economic burden placed by immigrants on the local population's welfare seems to be one of the main drivers of hostility toward refugees (Preston, 2014). In fact, a larger refugee population can intensify existing problems associated with economic scarcity (Dancygier, 2010). This is consistent with the work of Homer-Dixon (2010), who contends that the likelihood of violence increases with scarce resources. Alternatively, as people migrate to other areas to escape resource scarcity, we may see clashes with native populations over resource access or the distribution of goods. Refugees also compete with locals over limited public services such as food assistance, housing support, or medical services. Indeed, the very presence of refugees may generate grievances and tensions between natives and the refugees - especially if the former see refugees as a threat or feel that refugees are depriving the local population of what is rightfully theirs (Chambers, 1986; Weiner, 1992; Savun \& Gineste, 2017; Fjelde \& von Uexkull, 2012) ? $^{3}$ Overall, this discussion leads to the formulation of our first, unconditional hypothesis:

Hypothesis 1: The risk of non-state violence increases with the number of refugees in a country.

\section{The mediating effect of state capacity}

Without ignoring the humanitarian and moral aspects of the plight of refugees, host states could experience difficulties in trying to manage or accommodate refugees, which may generate popular grievances and violence against refugees. It seems plausible that the negative externality accompanying hosting refugee populations will be more severe and the ability to control violence lower in weak states, i.e., countries that are characterized by a low level of state capacity. In the following, we argue that state capacity mitigates the conflict-generating aspects of refugee populations. To this end, we focus on the administrative capacity of a high-capacity state to develop and disseminate information and (re-) distribute goods and services in an effective manner (see Hendrix, 2010). We see the strength of the bureaucratic apparatus as the most important aspect of state capacity; in particular, we look at the quality of public and civil service, including its independence from political pressures, the quality of policy formulation and implementation, as well as the credibility of the government's commitment to such policies. Hence, we focus on the 'economic capacity' to provide public goods and, as a result, to reduce the grievances of the population rather than the 'security capacity' to deter violence directly.

Particularly important for our purposes, Adamson $(2006,176)$ shows that refugees can 'overwhelm a state's capacity to provide public services and can lead to conflicts over resources'. Most of the world's refugees are

\footnotetext{
${ }^{3}$ The appendix elaborates on the underlying, micro-level implications of this macro-level framework.
} 
hosted in poor countries where already rather weak state institutions are put under additional pressure 4 In the words of Dowty \& Loescher (1996, 47), 'the cost falls disproportionately on nations least able to afford it, where the presence of large impoverished refugee populations further strains resources and perpetuates the poverty of the host nation. Refugees need water, food, fuel, and land; the environmental impact in already-marginal areas may be devastating. [...] They require social services beyond those provided by international agencies, putting further strain on domestic structures that may already have been inadequate'. At the same time, Sundberg et al. (2012) show that developing countries, in particular in Africa, see the largest number of non-state conflicts, suggesting that existing pressures on weak states are likely to increase as a large number of refugees can worsen the competition over already scarce resources. Although low-capacity states have limited ability to provide services or ensure sustainable livelihoods, they are particularly poorly suited to manage pressures arising from refugees. Not surprisingly, states 'with high levels of institutional capacity are in a much better position to adapt to this new environment than are weak or failing states' (Adamson, 2006, 176).

We claim accordingly that the quality of state institutions is likely to play a major role in shaping and addressing possible tensions between refugees and locals, and preventing instances of non-state violence in the presence of large refugee populations. According to the IMF (2016), the impact of refugees on medium and long-term economic prospects hinges on how countries manage to integrate refugees in the labor market (see also Maystadt \& Verwimp, 2014). Successfully addressing the challenges associated with refugees and responding to their needs effectively will be more difficult in societies with inadequate social welfare provision and no income support or unemployment benefits. All this depends on the quality and professionalism of the state apparatus a key feature of our understanding of state capacity. Countries with more professional institutions are likely to be in a better position to minimize the negative social and economic aspects linked to refugee populations. In turn, this should reduce the risk of tensions between refugees and locals and the likelihood that this will foster non-state violence.

As an illustrative example, consider how states differ in their ability to factor in the challenges associated with the arrival of refugees. According to the OECD (2015, 13), for example, European countries have long established introduction programs for refugees, generally related to language training, but also with a focus on labor-market integration, which is vital for 'migrants' economic independence, and a precondition for a positive economic impact of migration'. Nations with strong state capacity could even reap many benefits from access to a greater pool of skilled workers, which might promote technological innovation, stimulate economic growth, and redistribute gains to compensate potential losers. Immigrants are carriers of a variety of ideas and abilities, and the economic benefits of increased openness to immigration will tend to outweigh the economic costs, at least in the aggregate. Thielemann (2018) suggests here that when larger and more capable states accept to host large numbers of asylum seekers, they make a significant contribution to the provision of regional stability by reducing the scale of unregulated movement and stabilizing volatile situations.

Ultimately, the degree to which organized non-state actors are involved in episodes of violence depends on

${ }^{4}$ This is stressed in a report from the Brookings Institution, available online at https://www.brookings.edu/wp-content/ uploads/2017/01/global_20170109_foresight_africa.pdf 
the level of state capacity. In light of this discussion, although refugee flows can generate economic strains and pressures for violence, states with a high level of economic capacity can offer a sufficient level of public good provision and an effective economic and social integration so as to ensure peaceful cohabitation. Where the state is weak, however, there is little to prevent tensions between refugees and the local populations from emerging $5^{5}$ We thus expect that any effect of refugee populations on a higher risk of non-state violence should be conditional on state capacity. Support for integration, access to social services, and better infrastructure can reduce the tensions between refugees and locals - and, thus, the risk of non-state violence.

Hypothesis 2: State capacity conditions the effect of refugees on the risk of non-state violence.

\section{Research design}

Data, dependent variables, and methodology

We constructed a time-series cross-section data set containing all countries between 1989 and 2015, using the country-year as the unit of analysis. The time period is determined by the data availability for our variables. A central aspect of our theoretical argument is that many of the mechanisms through which refugees are meant to increase the risk of conflict include tensions with locals. But this does not entail clear grievances against the state authorities as such, especially if local populations see refugees as responsible. An implication of this claim is that refugee populations are likely to be associated with non-state conflict, but not necessarily with a higher likelihood of a full-scale civil war involving the host country's government as a belligerent. Against this background, in a first step, we conduct an empirical analysis where we jointly model peace, non-state conflict, and civil war as separate outcomes in a multinomial logistic regression framework. The goal of this analysis is to show that there may not be a significant or substantive influence of refugees on civil conflict as the outcome, at least in the absence of a cleavage for mobilization exacerbated by refugee inflows. After having established this finding, we then concentrate on non-state conflict as the outcome with logistic regression models.

The first dependent variable for the multinomial regression analysis codes for each country-year whether there was no conflict at all (0; we use this outcome value as the baseline category), non-state conflict (1), or civil conflict (2). Our data source for value 1 of that item (and the binary dependent variable described below) is the UCDP Non-State Conflict Dataset (Sundberg et al., 2012, Melander et al., 2016), which defines non-state conflicts as 'the use of armed force between two organized armed groups, neither of which is the government of a state, which results in at least 25 battle-related deaths in a year'. Organized groups are defined either formally or informally. The former refers to 'any non-governmental group of people having announced a name for their group and using armed force against another similarly formally organized group'. The latter comprises 'any group without an announced name, but who uses armed force against another similarly organized group, where there is a clear pattern of violent incidents that are connected and in which both groups use armed force

\footnotetext{
${ }^{5}$ Note that in countries with high levels of state capacity, social services provided through government funding are also targeted at native communities, which significantly reduces concerns over locals having a limited access to public services.
} 
against the other'. The Non-State Conflict Dataset excludes incidents of one-sided violence, where organized groups use violence against unorganized civilians ${ }^{6}$ Moreover, violence by unorganized individuals such as hate crimes against refugees and riots by refugees or local populations are not included as they do not meet the group criterion and are spontaneous rather than organized 7 However, note that the data are not limited to formal organizations but also include 'informally organized groups [...] without an announced name, [...] who use armed force against another similarly organized group', and cover 'communal violence [...] between very broad categories of identification', with the codebook citing the case of Hindus vs. Muslims in India as an example. We see non-state conflict onset in about $2.7 \%$ of the 5,118 observations in our sample.

The data on civil conflict (value 2 of the nominal dependent variable) are taken from Gleditsch et al. (2002) and Themnér \& Wallensteen (2012), and we employ the 25 battle-deaths threshold to define onsets. We convert the recorded instances of non-state or civil conflicts since 1989 to binary variables indicating the onset of (at least) one non-state or state-based conflict in a given country-year. Since we focus on onset, we drop all ongoing conflict years from the analyses, and a country with past conflict only enters the analysis in the first non-conflict year (following the definitions above). In turn, we use this information to construct the nominal variable for the multinomial regression analysis. Note that non-state violence onset and civil conflict onset occurred in 13 observations at the same time, while there are 68 cases in which ongoing non-state conflict and ongoing civil-conflict years overlap. We drop these country-years to ensure that the categories of the dependent variable for the multinomial regression are mutually exclusive.

The outcome variable for our second set of analyses is binary and we use logistic regression models as a result. This dichotomous dependent variable comprises all onsets of non-state violence, regardless of whether these overlap with state-based civil conflict onsets or incidence. The standard errors in either the multinomial regression or the logit models are clustered by country to control for potential differences in the variance between states.

\section{Explanatory variables}

Our argument focuses on refugee populations, state capacity, and the interaction of these two variables as we expect the latter to moderate the effect of the former on the risk of, particularly, non-state actor conflict. First, for refugee populations, we rely on the UNHCR Population Statistics Reference Database. These data provide information on the number of different 'population types' per country year. We concentrate on refugees, persons in refugee-like situations, and asylum seekers as the relevant population types, and calculate the total number of these groups in a country-year. Internally displaced persons or returnees are excluded from our measure, since these sub-populations are likely to differ in important ways from those populations we focus on. Based

\footnotetext{
${ }^{6}$ Although the UCDP also collects data on one-sided violence by non-state actors, we show in the appendix that these are largely confined to actors involved in a state-based civil conflict. Hence, although we could see one-sided violence by organized non-state actors against refugees, such events will not be systematically captured by existing data, largely limited to situations with ongoing or recent civil conflict. Evaluating one-sided violence against refugees would also benefit from information on victims to assess whether refugees are specifically targeted. Although we see more one-sided violence by governments against civilians outside civil war Savun \& Gineste 2019), governments are unlikely to have incentives to target refugees unless they perceive a high risk of organized violence, which would suggest a higher risk of civil conflict.

${ }^{7}$ See Savun \& Gineste $(2017)$ on refugee riots and Koopmans \& Olzak $(2004)$ on hate crimes.
} 
on the raw data from the UNHCR, we replaced missing observations by 0s and we added the value of 1 before taking the natural logarithm of the total number of refugees to arrive at the final item, Refugees (ln) (mean value of 6.565 ; standard deviation of 4.495). The pairwise correlation between Non-state conflict and Refugees $(\ln )$ is $0.084(\mathrm{p}<0.001)$.

Second, although state capacity is a potentially multidimensional concept that is challenging to measure (see also Hendrix, 2010), we focus on state capacity pertaining to the strength and quality of the bureaucratic apparatus. Countries with an effective bureaucracy are most likely to be able to maintain, control, and sustain state services. Similarly, Fukuyama (2013) argues that measures of state capacity based on what the state produces are problematic and, instead, suggests that state capacity is best to be measured by looking at how governments function, specifically bureaucratic procedures, capacity, and autonomy. We capture this empirically by the Worldwide Governance Indicators (WGI), which report aggregate governance indicators for more than 200 countries in 1996-2015. These data are based on enterprise, citizen, and expert survey respondents in industrial and developing states, and further incorporate information from over 30 individual data sources (e.g., survey institutes, think tanks, non-governmental organizations, international organizations, or private sector firms). The specific variable we focus on, namely government effectiveness, is intended to capture perceptions of the quality of public services, the quality of the civil service and the degree of its independence from political pressures, the quality of policy formulation and implementation, and the credibility of the government's commitment to such policies.

The WGI measure is widely used in the literature, but the temporal scope is limited in that data before 1996 are not available. To overcome this, we rely on an alternative indicator from the Political Risk Services Group's (PRSG) International Country Risk Guide, which is based on expert assessments on a state's bureaucratic quality and ranges in $[0 ; 4]$. According to the PRSG, 'high points are given to countries where the bureaucracy has the strength and expertise to govern without drastic changes in policy or interruptions in government services. In these low-risk countries, the bureaucracy tends to be somewhat autonomous from political pressure and to have an established mechanism for recruitment and training. Countries that lack the cushioning effect of a strong bureaucracy receive low points because a change in government tends to be traumatic in terms of policy formulation and day-to-day administrative functions'. We combine the two variables by interpolating missing values of the WGI variable using information from the PRSG. The final variable, State capacity, is thus an interpolated version of the WGI item covering the period from 1989 to 2015, and its pairwise correlation with Non-state conflict is $-0.091(\mathrm{p}<0.001)$. It has a mean value of -0.028 with a standard deviation of 0.966 . Note that refugees are present in countries of all levels of state capacity, with or without non-state conflict. Finally, we include a multiplicative interactive term between Refugees (ln) and State capacity to examine whether state capacity moderates the effect of refugees.

With regard to the control variables, we consider a series of other covariates reflecting alternative influences leading to the outbreak of non-state conflict that are also plausibly associated with refugees and state capacity. First, taken from the World Bank Development Indicators, we control for a country's midyear total population, 
which counts all residents regardless of legal status or citizenship - however, refugees not permanently settled are included only in Refugees (ln). Second, we use an indicator for democracy based on the 21 point combined polity score from the Polity IV database, ranging from -10 to 10, with higher values reflecting states with more democratic institutions (Marshall \& Jaggers, 2016). As this particular democracy measure might be endogenous to factional non-state conflict, we use the modified XPolity variable by Vreeland (2008). Since some work on regime type and civil war suggests that partly democratic countries are more prone to conflict than both full democracies and full autocracies (Hegre et al. 2001), we also include the square term of XPolity as well.

Third, we consider the share of population in excluded ethnic groups, based on the Ethnic Power Relations (EPR) data (see Cederman et al., 2010, Wimmer et al., 2009). According to the EPR data, included/excluded ethnic groups are defined by ethnicity and their access to power. Excluded groups (largely) lack access to executive power, i.e., representation in the presidency, the cabinet, and senior posts in the administration, including the army. Ethnic groups are also excluded if they are discriminated, powerless, or have regional or separatist autonomy. For our specific question, ethnic exclusion and tensions might not only affect the risk of non-state conflict, but also the degree of state capacity and refugees' self-selection into host societies: it is plausible that refugees may avoid fleeing to countries that have significant ethnic tensions manifested in political exclusion of ethnic groups. We use the normalized share of the population in excluded groups.

Finally, to address temporal dependencies in the analysis using our nominal outcome variable, we calculate cubic polynomials based on the time elapsed (in years) since the last conflict onset (if any and however defined it may be, i.e., non-state conflict or civil conflict) following Carter \& Signorino (2010). As the outcome variable for our second set of analyses differs from the multinomial regressions, we adjust the variables for temporal correction accordingly (i.e., the time elapsed since the last onset of non-state violence, its squared term, and this variable raised to the power of 3$)$.

\section{Empirical findings}

Table I and Figure II summarize our findings based on the multinomial logistic regression analysis. First, our coefficient estimates for the non-state conflict outcome suggest that state capacity can mitigate the negative externalities in the relationship between refugee populations and non-state violence. Second, when coming to the results for the civil-conflict outcome, however, our main variables of interest - with the exception of State capacity - are no longer statistically significant. Figure II supports these conclusions. We plot average marginal effects of Refugees (ln) on Non-state conflict (left panel) and Civil conflict (right panel). The pattern in the left panel of Figure II shows, in line with our expectations, that the marginal effect of Refugees (ln) is positive and significant for low levels of State capacity, but becomes insignificant with higher values of the latter. However, this differs from the civil-conflict context (right panel), where the influence of refugees is statistically insignificant at any value of State capacity $\unlhd^{8}$

\footnotetext{
${ }^{8}$ Our results for civil war are not directly comparable to Salehyan \& Gleditsch $(2006)$, though. We do not impose their suggested scope restriction to refugees from neighboring countries, while Salehyan \& Gleditsch (2006) do not consider an interaction between refugees and state capacity. Our main purpose here is not to examine the more specific conditions under which refugees can increase
} 
Table I. Non-state actor violence and civil conflict: Refugees and state capacity

\begin{tabular}{|c|c|c|}
\hline & Model 1: Non-state violence & Model 1: Civil conflict \\
\hline \multirow[t]{2}{*}{ Refugees (ln) } & 0.029 & 0.104 \\
\hline & $(0.053)$ & $(0.068)$ \\
\hline \multirow[t]{2}{*}{ State capacity } & 0.560 & $-1.718^{* *}$ \\
\hline & $(0.397)$ & $(0.583)$ \\
\hline \multirow[t]{2}{*}{ Refugees $(\ln ) \times$ State capacity } & $-0.091^{*}$ & 0.097 \\
\hline & $(0.041)$ & $(0.060)$ \\
\hline \multirow[t]{2}{*}{ Population (ln) } & $0.432^{* *}$ & $0.232^{* *}$ \\
\hline & $(0.118)$ & $(0.084)$ \\
\hline \multirow[t]{2}{*}{ XPolity } & $0.164^{* *}$ & -0.027 \\
\hline & $(0.059)$ & $(0.033)$ \\
\hline \multirow[t]{2}{*}{ XPolity $^{2}$} & $-0.042^{* *}$ & -0.006 \\
\hline & $(0.013)$ & $(0.011)$ \\
\hline \multirow[t]{2}{*}{ Excluded population } & 0.482 & 0.156 \\
\hline & $(0.828)$ & $(0.509)$ \\
\hline \multirow[t]{2}{*}{ Peace years } & -0.262 & $-0.556^{* *}$ \\
\hline & $(0.143)$ & $(0.116)$ \\
\hline \multirow[t]{2}{*}{ Peace years ${ }^{2}$} & 0.011 & $0.034^{* *}$ \\
\hline & $(0.016)$ & $(0.013)$ \\
\hline \multirow[t]{2}{*}{ Peace years ${ }^{3}$} & 0.000 & -0.001 \\
\hline & $(0.000)$ & $(0.000)$ \\
\hline \multirow[t]{2}{*}{ Constant } & -9.636 & $-6.840^{* *}$ \\
\hline & $(2.030)$ & $(1.457)$ \\
\hline Obs. & & 3,204 \\
\hline Pseudo log likelihood & & -449.688 \\
\hline Prob $>\chi^{2}$ & & 0.000 \\
\hline
\end{tabular}

In the following, we focus on non-state conflict as the outcome variable. We present four additional models in Table II. Model 2 only includes the variables correcting for temporal dependence and State capacity in order to show that there is an independent effect stemming from the moderating variable. Model 3 provides an estimation with only the temporal controls and all our main explanatory variables, excluding the substantive control items. Model 4 includes the temporal controls and other control covariates, but we omit Refugees (ln) and the interaction term. Model 5 is our full estimation where all explanatory items are considered. Figure III depicts the average marginal effects of Refugees $(l n)$ for given values of State capacity. The left panel of Figure III shows the substantive effects of our variables of interest for Model 3, whereas the right panel summarizes the average marginal effects associated with Refugees (ln) for Model 5. As expected, a larger number of refugees in a country is associated with a higher risk of non-state actor conflict, but only when countries have little state capacity. For example, increasing Refugees (ln) from its minimum to its maximum while holding State capacity at -2 (with all other variables in Model 5 held constant at their means) increases conflict risk from $0.8 \%$ to $6.8 \%$ - an increase of $6 \%$-points. This is mirrored by the average marginal effect of Refugees (ln), which is positive and statistically significant at conventional levels for low values of State capacity. In both the left and the right panel of Figure III, these effects become statistically insignificant for higher levels of State capacity. To this end, the point estimate for the predicted probability of conflict risk decreases when changing Refugees the risk of civil war, but rather the more direct relationship to non-state conflict. 
Figure II. Non-state actor violence and civil conflict: Refugees and state capacity in a multinomial logistic framework
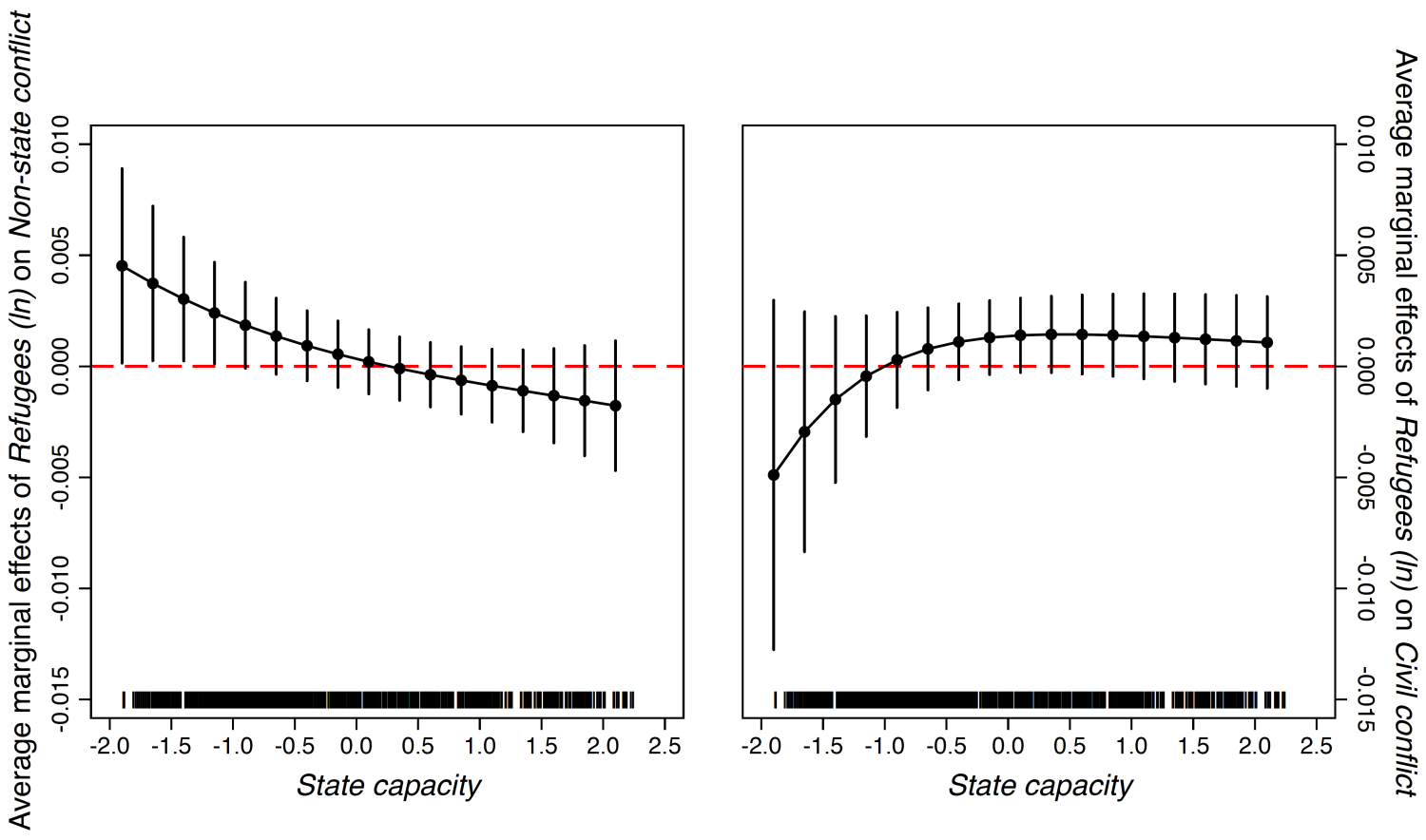

Note: Graph shows average marginal effects of Refugees $(l n)$ conditional on State capacity, while holding all other covariates constant at their means; vertical bars signify $95 \%$ confidence intervals; rug plots at horizontal axes illustrate distribution of State capacity; left panel pertains to Non-state conflict; right panel pertains to Civil conflict.

(ln) from its minimum to its maximum while holding State capacity at +2 (all other variables hold constant at their means) from 0.021 to 0.002 ; both estimates are statistically insignificant, however, based on Model 5 . The risk of non-state conflict in low-capacity states increases with an influx of refugees, but remains rather low. As discussed above, this refers to a rise of about $6 \%$-points when moving from the minimum to the maximum of the item on refugee populations.

These results strongly and robustly support our theoretical argument. As an illustrative case, consider Lebanon, which had one of the largest refugee populations in the world in 2015 (about 1.08 million refugees), and a rather low state capacity (-0.471). According to a recent report by Human Right Watch 9 the Syrian refugee crisis coupled with limited international support and the government's failure to provide basic services has led to a resurgence of violence in the country. Recent years have witnessed an increase in the number of "vigilante-style attacks' directed at the large Syrian refugee population (Reuters, July 25, 2016) and, even in absence of visible attacks, aid agencies are increasingly concerned by a hostile shift in public opinion (NPR, September 2, 2017). Already inaccessible and in poor condition, the Lebanese public-health care system was particularly unprepared to deal with large numbers of refugees. Several assessments show that worsening living standards are closely connected to rising inter-communal tensions, particularly over access to social and municipal services Ghanem, 2014 Mercy Corps, 2017). According to Maria Assi, the CEO of Beyond Association, an organization helping refugees in Lebanon, the upsurge in hostilities is caused by a 'failure of the government and international aid agencies to put in place a long-term strategy to help the country adapt to the increase in population' (NPR,

\footnotetext{
${ }^{9}$ Available online at: https://www.hrw.org/world-report/2017/country-chapters/lebanon
} 
Table II. Non-state actor violence: Refugees and state capacity

\begin{tabular}{|c|c|c|c|c|}
\hline & Model 2 & Model 3 & Model 4 & Model 5 \\
\hline Refugees (ln) & & $\begin{array}{c}0.089^{*} \\
(0.041)\end{array}$ & & $\begin{array}{r}-0.002 \\
(0.034)\end{array}$ \\
\hline State capacity & $\begin{array}{c}-0.466^{* *} \\
(0.151)\end{array}$ & $\begin{array}{r}-0.081 \\
(0.484)\end{array}$ & $\begin{array}{r}-0.368^{*} \\
(0.153)\end{array}$ & $\begin{array}{c}0.261 \\
(0.306)\end{array}$ \\
\hline Refugees $(\ln ) \times$ State capacity & & $\begin{array}{r}-0.044 \\
(0.049)\end{array}$ & & $\begin{array}{r}-0.075^{*} \\
(0.032)\end{array}$ \\
\hline Population $(\ln )$ & & & $\begin{array}{l}0.468^{* *} \\
(0.082)\end{array}$ & $\begin{array}{l}0.473^{* *} \\
(0.092)\end{array}$ \\
\hline XPolity & & & $\begin{array}{c}0.091^{*} \\
(0.036)\end{array}$ & $\begin{array}{c}0.078^{*} \\
(0.035)\end{array}$ \\
\hline XPolity $^{2}$ & & & $\begin{array}{c}-0.031^{* *} \\
(0.008)\end{array}$ & $\begin{array}{c}-0.027^{* *} \\
(0.007)\end{array}$ \\
\hline Excluded population & & & $\begin{array}{c}1.047 \\
(0.561)\end{array}$ & $\begin{array}{c}0.843 \\
(0.521)\end{array}$ \\
\hline Peace years & $\begin{array}{r}-0.126 \\
(0.087)\end{array}$ & $\begin{array}{r}-0.102 \\
(0.082)\end{array}$ & $\begin{array}{c}-0.050 \\
(0.101)\end{array}$ & $\begin{array}{r}-0.038 \\
(0.101)\end{array}$ \\
\hline Peace years ${ }^{2}$ & $\begin{array}{r}-0.008 \\
(0.009)\end{array}$ & $\begin{array}{r}-0.009 \\
(0.009)\end{array}$ & $\begin{array}{c}-0.010 \\
(0.011)\end{array}$ & $\begin{array}{c}-0.011 \\
(0.011)\end{array}$ \\
\hline Peace years ${ }^{3}$ & $\begin{array}{c}0.000 \\
(0.000)\end{array}$ & $\begin{array}{c}0.000 \\
(0.000)\end{array}$ & $\begin{array}{c}0.000 \\
(0.000)\end{array}$ & $\begin{array}{c}0.000 \\
(0.000)\end{array}$ \\
\hline Constant & $\begin{array}{c}-2.333^{* *} \\
(0.246)\end{array}$ & $\begin{array}{c}-3.122^{* *} \\
(0.439)\end{array}$ & $\begin{array}{c}-10.190^{* *} \\
(1.574)\end{array}$ & $\begin{array}{c}-10.289^{* *} \\
(1.654)\end{array}$ \\
\hline Obs. & 4.293 & 4.293 & 3.686 & 3.686 \\
\hline Pseudo log likelihood & -496.158 & -483.936 & -398.345 & -395.243 \\
\hline Prob $>\chi^{2}$ & 0.000 & 0.000 & 0.000 & 0.000 \\
\hline
\end{tabular}

September 2, 2017). Although Lebanon has not seen renewed conventional civil conflict following the influx of refugees, the fact that Lebanon has seen the onset of non-state violence according to our definition in 2015 is consistent with the expectations from the model estimates.

Table III. Substantive effects of control variables

\begin{tabular}{lccc}
\hline & First difference & $\begin{array}{c}\text { Lower bound } \\
\mathbf{( 9 5 \% )}\end{array}$ & $\begin{array}{c}\text { Upper bound } \\
\mathbf{( 9 5 \% )}\end{array}$ \\
\hline Population (ln) & 0.115 & 0.052 & 0.209 \\
XPolity $^{2}$ & 0.011 & 0.001 & 0.022 \\
XPolity $^{2}$ & -0.020 & -0.038 & -0.007 \\
Excluded Population $^{2}$ & 0.016 & -0.003 & 0.047 \\
\hline
\end{tabular}

Finally, for the control variables we evaluate their substantive implications in Table III, which summarizes first differences for each variable, i.e., changes in the predicted probability of non-state actor conflict risk for a variable at its maximum value compared to its minimum value, holding all other variables constant at their means. First, as expected, population is positively associated with conflict risk. For example, conflict risk increases by about 11.5\%-points when moving from the minimum to the maximum of Population (ln). The excluded ethnic-population variable is statistically insignificant. We also plot the curvilinear effect of XPolity in the appendix, which shows that the likelihood of conflict is highest at 'mixed regimes', i.e., anocracies, which is in line with earlier studies on regime type and conflict. 
Figure III. Non-state actor violence: Refugees and state capacity
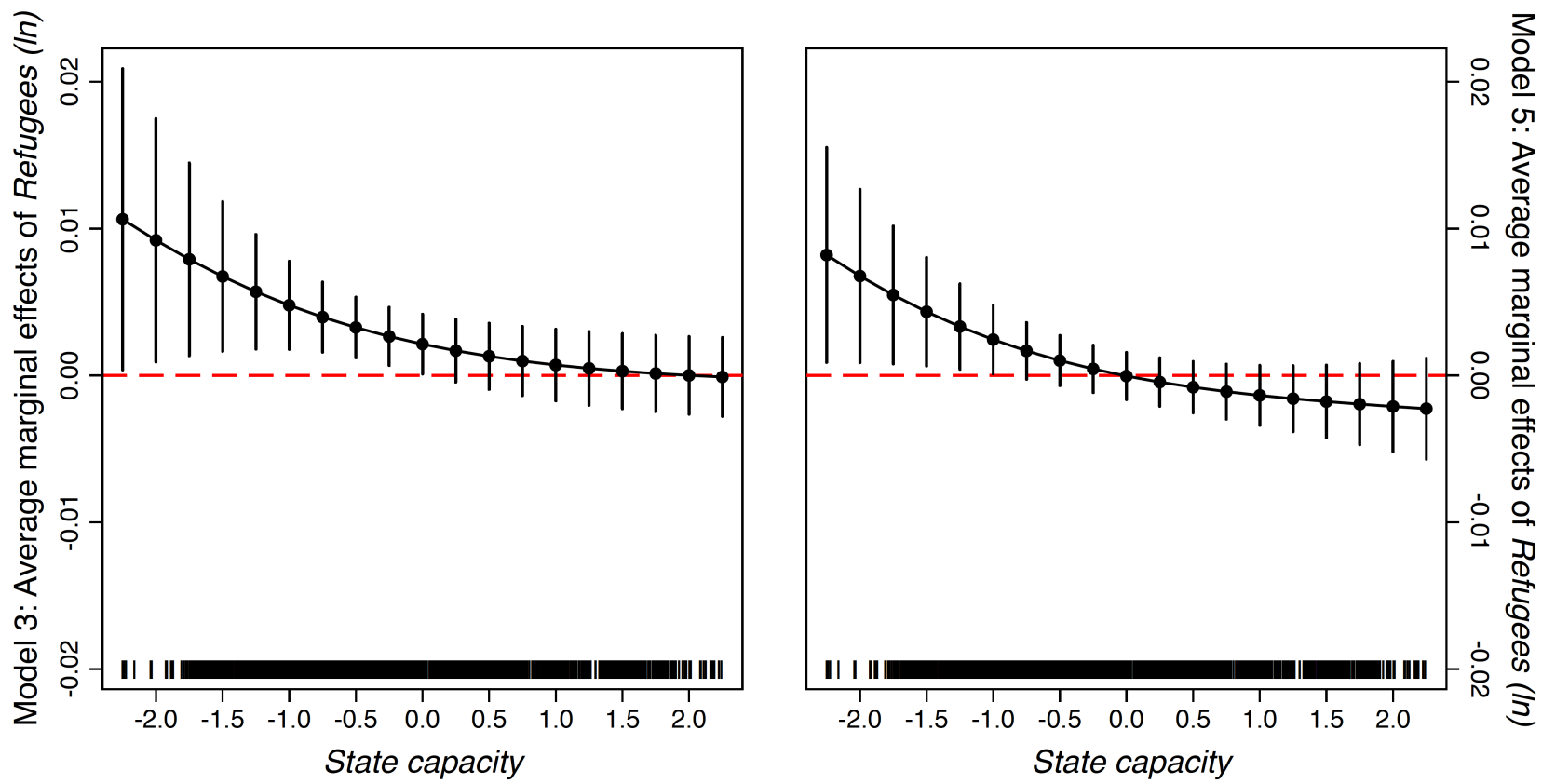

Note: The figure shows average marginal effects of Refugees (ln) conditional on State Capacity, while holding all other covariates constant at their means; vertical bars signify $95 \%$ confidence intervals; rug plots at horizontal axes illustrate distribution of State Capacity.

To assess the robustness of our results, we examined various alternative specifications for the main logistic regression model (Model 5), which are discussed in the appendix. Here, we briefly describe the three most important additional analyses. First, our operationalization of Refugees $(l n)$ is based on the number of refugees, not shifts or changes. It seems plausible, however, that our argument may work for the latter as well. The appendix summarizes the corresponding results: the average marginal effects of Refugee change (ln) decrease with higher values of State capacity, ultimately rendering the impact statistically insignificant. Hence, employing levels or changes for the refugee-population variable does not affect our core conclusions. Second, we replicate our main model when using the non-interpolated version of the WGI and the bureaucratic-quality item from the PRSG, respectively. Third, we include an additional control on the number of refugee camps in a country. Interestingly, the item for refugee camps is associated with an insignificant coefficient estimate. This suggests that there are competing mechanisms at work, which cancel each other out and, eventually, lead to the overall insignificance of the item. While Savun \& Gineste (2017) contend that more concentrated refugee populations are more easily controllable, Onoma (2013) outlines that refugees are frequently targeted in times of civil war - and this might be facilitated as refugee populations are more concentrated in camps (see also Lischer, 2005. Fisk, 2014, 2019, Shaver \& Zhou, 2017).

\section{Conclusion}

A central claim of our research is that high-intensity forms of organized political violence are unlikely to be linked to refugees. Lower-intensity forms of violence seem, ex-ante and if anything, more plausibly linked to 
refugee populations, and we should also focus on types of conflict that do not see the state as the central actor. Our article extends existing work on refugees and conflict by analyzing the implications for non-state conflict. The main argument is that refugees can - directly or indirectly - be associated with non-state forms of violence, but primarily when state institutions are weak. The presence of refugees results in social and economic challenges that weak states are less prepared to take measures necessary to prevent (see also Chambers, 1986).

The moderating influence of state capacity is important, as developing and emerging countries host the most refugees and suffer disproportionately. Indeed, our results run completely counter to the security rationale cited for efforts to restrict refugee inflows in the USA and many European countries. A key implication of our analysis is that the risk of non-state conflict remains low despite high inflows when hosting states have high capacity. The relevant security implications arise in low-capacity, developing countries. In part as a result of the problems of achieving a proportionate global burden sharing and the reluctance of many developed countries to accept refugees (Bauböck, 2018), UNHCR estimates indicate that as many as $84 \%$ of the world's refugees are hosted in developing countries least prepared to deal with the challenges. If fleeing and fighting are potential substitutes (Okamoto \& Wilkes, 2008), efforts to crack down on opportunities for refugees or asylum institutions risk exacerbating conflicts and their devastating impact in the countries of origin, with potentially worse consequences for neighboring states. Hence, our results should also not be interpreted as evidence in favor of exclusionary policies in low-capacity states against refugees from neighboring countries, as limits to opportunities for asylum can exacerbate neighboring conflict and generate even more severe transnational security challenges from conflicts.

The link between state capacity and non-state conflict from hosting refugees may seem to have largely negative policy implications, in that many states hosting refugees lack the capacity to implement measures that could be effective in mitigating the risks of violence. However, state capacity is not just determined by domestic forces, and resources from outside a country can also be important to compensate for limited domestic capacity. Many European nations have developed better settlement services for refugees over the course of the recent crisis, and some of this capacity could, at least in principle, be transferred to vulnerable countries hosting refugees closer to ongoing conflicts. Third-party assistance that can raise host countries' capacities may help these to address the difficulties in trying to manage the arrival of refugees in a way that does not undermine local service provision and generate popular grievances, before tensions arise and the risk of non-state violence increases. For this to happen, states must be less concerned with burden shirking, and steer more foreign assistance and development aid to state-capacity building measures in receiving nations (also Chambers, 1986).

Several avenues for future research might emerge out of our work. Since previous research has paid limited attention to the multi-dimensional character of state capacity (Fukuyama, 2013; Migdal, 2001), disaggregating our measure of state capacity based on bureaucratic quality may be helpful. Studying how a more differentiated measure of state capacity plays out with respect to authority and legitimacy might also be an effort worth making (see also Tikuisis \& Carment, 2017), and we believe that shedding more light on the willingness and opportunity aspects of state capacity can significantly improve our understanding of how state capacity mediates 
the security implications of refugee flows. Our current state-capacity measure combines states' willingness to use their resources with the possibilities they have at their disposal. However, in some cases, a government may actually have the necessary resources, but simply lack the willingness to invest them.

Second, it would be interesting to expand the analysis of non-state conflict to other forms of political violence in varying degrees of organization and the relationship between them, as well as variation in intensity and severity. One-sided violence, hate crimes, violence by paramilitary and militia groups could all be interesting alternatives we should study. In addition, non-state actor violence may well be associated with state-based civil conflict in that the former may increase the risk of the latter or that the latter positively influences the onset of non-state conflict. Our multinomial regression analysis assumes that these two alternatives are unrelated to each other at the point of onset, but there may be more complex relationships between one type of conflict and the risk of others over time that are worthy of further investigation. A full analysis of the relationship between different forms of violence goes beyond the scope of this article, but we provide a preliminary analysis based on a simultaneous-equations model in the appendix. This suggests some evidence that non-state conflict may deter refugees and that states with lower state capacity may receive more refugees, but there is little evidence for a clear relationship from non-state conflict to civil war.

Finally, our outcome variable in its present form cannot determine whether refugees are the source or the target of violence - or not directly involved in violence at all. This is in line with our theory, and the specific propositions we consider do not require that refugees must be the target or source of non-state violence. However, Onoma (2013) or Cuellar (2006) provide case studies indicating that refugees are often targeted in civil wars. Moreover, parts of our theoretical discussion and the Rohingya illustration also show that refugees frequently become targets of non-state violence in weak states because of the actual or perceived negative externalities they pose. Stigmatizing refugees seems therefore even more misleading, and victims should indeed not be blamed, but the lack of coding of targets in conflict in current data prevent a more thorough analysis. Hence, additional coding efforts to distinguish between refugees as the source or target of violence are necessary. Savun \& Gineste (2019), Gineste \& Savun (2019), or Polo \& Wucherpfennig (2017) have begun to pursue this promising avenue of research; in addition, Fisk (2014) provides spatially disaggregated conflict and refugee data in 26 African countries for 2000-2010, while Shaver \& Zhou (2017) have compiled geo-coded data on UNHCR refugee sites in 1989-2008.

We conclude that no state is inherently unable to deal with refugees, and there is no automatic link between hosting more refugees and a higher likelihood of political violence. Our evidence helps to clarify the consequences that can be anticipated and what policies could be enacted. If governments are concerned about tensions in countries affected by the humanitarian impact of refugee crises and migration, efforts should be made to strengthen state capacity and the ability to integrate refugees into the local economy (see also Savun \& Gineste, 2017). Blaming refugees for heightened security risks or simply closing borders to people in need of asylum entails large humanitarian consequences and can be counterproductive. It is unlikely that people will stop fleeing conflict and persecution, and efforts to close borders are likely to increase the burden on weaker states and force 
refugees to seek more risky routes with a high loss of life. We recognize the significant challenges to asylum systems, as host states need to mobilize resources to minimize the difficulties they could be experiencing in trying to manage the arrival of refugees so that the provision of public goods is not undermined and grievances among the local population are not generated. In many countries, the scale of the current refugee crisis leaves existing systems for accommodating and processing refugees under severe strain. But failing to implement comprehensive and well-tailored policies to strengthen receptive and processing capabilities and to support integration efforts will make refugee flows more costly for host societies in the long run.

\section{References}

Adamson, Fiona (2006) Crossing borders: International migration and national security. International Security 31(1): 165-199.

Bauböck, Rainer (2018) Refugee protection and burden-sharing in the European Union. Journal of Common Market Studies 56(1): 141-156.

Bove, Vincenzo \& Tobias Böhmelt (2016) Does immigration induce terrorism? Journal of Politics 78(2): $572-588$.

Braithwaite, Alex (2010) Resisting infection: How state capacity conditions conflict contagion. Journal of Peace Research 47(3): 311-319.

Buhaug, Halvard \& Kristian S Gleditsch (2008) Contagion or confusion? Why conflicts cluster in space. International Studies Quarterly 52(1): 215-233.

Carter, David B \& Curtis S Signorino (2010) Back to the future: Modeling time dependence in binary data. Political Analysis 18(3): 271-292.

Cederman, Lars-Erik; Andreas Wimmer \& Brian Min (2010) Why do ethnic groups rebel? New data and analysis. World Politics 62(1): 87-119.

Chambers, Robert (1986) Hidden losers? The impact of rural refugees and refugee programs on poorer hosts. International Migration Review 20(2): 245-263.

Cuellar, Mariano-Florentino (2006) Refugee security and the organizational logic of legal mandates. Georgetown Journal of International Law 37(1): 583.

Cunningham, David E \& Douglas Lemke (2013) Combining civil and interstate wars. International Organization 67(3): 609-627.

Dancygier, Rafaela M (2010) Immigration and conflict in Europe. Cambridge: Cambridge University Press.

de Rouen, Karl \& David Sobek (2004) The dynamics of civil war duration and outcome. Journal of Peace Research 41(3): 303-320. 
Dowty, Alan \& Gil Loescher (1996) Refugee flows as grounds for international action. International Security 21(1): 43-71.

Fearon, James \& David Laitin (2003) Ethnicity, insurgency, and civil war. American Political Science Review 97(1): $75-90$.

Fisk, Kerstin (2014) Refugee geography and the diffusion of armed conflict in Africa. Civil Wars 16(3): 255-275.

Fisk, Kerstin (2018) One-sided violence in refugee-hosting areas. Journal of Conflict Resolution 62(3): 529-556.

Fisk, Kerstin (2019) Camp settlement and communal conflict in Sub-Saharan Africa. Journal of Peace Research 56: Forthcoming.

Fjelde, Hanne \& Gudrun Østby (2014) Socioeconomic inequality and communal conflict: A disaggregated analysis of Sub-Saharan Africa, 1990-2008. International Interactions 40(5): 737-762.

Fjelde, Hanne \& Nina von Uexkull (2012) Climate triggers: Rainfall anomalies, vulnerability, and communal conflict in Sub-Saharan Africa. Political Geography 31(7): 444-453.

Fukuyama, Francis (2013) What is governance? Governance 26(3): 347-368.

Ghanem, Nizar (2014) Search for common ground - Lebanon: Dialogue and local response mechanisms to conflict between host communities and syrian refugees in lebanon. Available at: https://data2. unhcr. org/en/documents/details/41354.

Gineste, Christian \& Burcu Savun (2019) Introducing posvar: A dataset on refugee-related violence. Journal of Peace Research 56: Forthcoming.

Gleditsch, Kristian S (2007) Transnational dimensions of civil war. Journal of Peace Research 44(3): 293-309.

Gleditsch, Kristian S \& Henrikas Bartusevičius (2018) A two-stage approach to civil conflict: Contested incompatibilities and armed violence. International Organization: Forthcoming.

Gleditsch, Kristian S \& Aaron Clauset (2018) Trends in warfare: What do we know, and what can we know? In: Alexandra Gheciu \& William C Wohlforth (eds) Handbook of International Security. Oxford: Oxford University Press: 227-245.

Gleditsch, Nils P; Peter Wallensteen; Mikael Eriksson; Margareta Sollenberg \& Håvard Strand (2002) Armed conflict 1946-2001: A new dataset. Journal of Peace Research 39(5): 615-637.

Hatton, Timothy (2016) Refugees, asylum seekers, and policy in OECD countries. American Economic Review 106(5): 441-445.

Hegre, Håvard; Tanja Ellingsen; Scott Gates \& Nils P Gleditsch (2001) Towards a democratic civil peace? Opportunity, grievance, and civil war 1816-1992. American Political Science Review 95(1): 33-48. 
Hendrix, Cullen (2010) Measuring state capacity: Theoretical and empirical implications for the study of civil conflict. Journal of Peace Research 47(3): 273-285.

Homer-Dixon, Thomas (2010) Environment, scarcity, and violence. Princeton, NJ: Princeton University Press.

IMF (2016) The refugee surge in europe: Economic challenges. IMF Staff Discussion Note. Available at: https: //www. imf.org/external/pubs/ft/sdn/2016/sdn1602. pdf.

Koopmans, Ruud \& Susan Olzak (2004) Discursive opportunities and the evolution of right-wing violence in Germany. American Journal of Sociology 110(1): 198-230.

Lischer, Sarah (2005) Dangerous sanctuaries: Refugee camps, civil war, and the dilemmas of humanitarian aid. Ithaca, NY: Cornell University Press.

Marshall, Monty \& Keith Jaggers (2016) Polity IV project: Political regime characteristics and transitions, 1800-2016. College Park, MD: University of Maryland.

Maystadt, Jean-François \& Philip Verwimp (2014) Winners and losers among a refugee-hosting population. Economic Development and Cultural Change 62(4): 769-809.

Melander, Erik; Therése Pettersson \& Lotta Themnér (2016) Organized violence, 1989-2015. Journal of Peace Research 53(5): 727-742.

Mercy Corps (2017) From tension to violence: Understanding and preventing violence between refugees and host communities in lebanon. Mercy Corps, Lebanon, Beirut. Available at: www. mercycorps. org.

Migdal, Joel (2001) State in society: Studying how states and societies transform and constitute one another. Cambridge: Cambridge University Press.

Milton, Daniel; Megan Spencer \& Michael Findley (2013) Radicalism of the hopeless: Refugee flows and transnational terrorism. International Interactions 39(5): 621-645.

OECD (2015) Is this humanitarian migration crisis different? OECD Migration Policy.

Okamoto, Dina \& Rima Wilkes (2008) Fight or flight: Understanding ethnic group migration and rebellion. Journal of Ethnic and Migration Studies 34(3): 347-369.

Onoma, Ato (2013) Anti-refugee violence and African politics. Cambridge: Cambridge University Press.

Polo, Sara \& Julian Wucherpfennig (2017) Refugees and the Spread of Terrorism: New Data and Analysis. Rice University: Typescript.

Preston, Ian (2014) The effect of immigration on public finances. Economic Journal 124(580): F569-F592.

Salehyan, Idean \& Kristian S Gleditsch (2006) Refugees and the spread of civil war. International Organization 60(2): 335-366. 
Savun, Burcu \& Christian Gineste (2017) Welcoming the unwelcome: Refugee flows, integration, and political violence. University of Pittsburgh: Typescript.

Savun, Burcu \& Christian Gineste (2019) From protection to persecution: Threat environment \& refugee scapegoating. Journal of Peace Research 56: Forthcoming.

Shaver, Andrew \& Yang-Yang Zhou (2017) Do refugees spread or reduce conflict? Harvard University: Typescript.

Sundberg, Ralph; Kristine Eck \& Joakim Kreutz (2012) Introducing the UCDP Non-State Conflict Dataset. Journal of Peace Research 49(2): 351-362.

Themnér, Lotta \& Peter Wallensteen (2012) Armed conflicts, 1946-2011. Journal of Peace Research 49(4): $565-575$.

Thielemann, Eiko (2018) Why refugee burden-sharing initiatives fail: Public goods, free-riding, and symbolic solidarity in the EU. Journal of Common Market Studies 56(1): 63-82.

Tikuisis, Peter \& David Carment (2017) Categorization of states beyond strong and weak. Stability: International Journal of Security and Development 6(1): 12: 1-23.

Vreeland, James (2008) The effect of political regime on civil war: Unpacking anocracy. Journal of Conflict Resolution 52(3): 401-425.

Weiner, Myron (1992) Security, stability, and international migration. International Security 17(3): 91-126.

Wimmer, Andreas; Lars-Erik Cederman \& Brian Min (2009) Ethnic politics and armed conflict: A configurational analysis of a new global data set. American Sociological Review 74(2): 316-337.

Zolberg, Aristide; Astri Suhrke \& Sergio Aguayo (1989) Escape from violence: Conflict and the refugee crisis in the developing world. Oxford: Oxford University Press. 